\title{
Pemanfaatan penginderaan jauh dalam penilaian keberhasilan reklamasi di lahan pasca tambang PT Vale Indonesia
}

\section{The use of remote sensing technology in assessing the success of reclamation in post-mining area at PT Vale Indonesia}

Munajat Nursaputra ${ }^{\mathrm{a}}$, Siti Halimah Larekeng ${ }^{\mathrm{b}}, \mathrm{Nasri}^{\mathrm{c}}$, Andi Siady Hamzah ${ }^{\mathrm{c}}$, Andi Subhan Mustari ${ }^{\mathrm{d}}$, Abdur Rahman Arife, $^{\text {Aris Prio Ambodo }}$, Yohan Lawang ${ }^{\mathrm{f}}$, Andri Ardiansyah ${ }^{\mathrm{f}}$

\footnotetext{
${ }^{a}$ Program Studi Kehutanan, Fakultas Kehutanan, Universitas Hasanuddin, Kampus UNHAS Tamalanrea Makassar, 90245, Indonesia

${ }^{\text {b }}$ Program Studi Rekayasa Kehutanan, Fakultas Kehutanan, Universitas Hasanuddin, Kampus UNHAS Tamalanrea Makassar, 90245 , Indonesia

${ }^{\mathrm{c}}$ Program Studi Konservasi Hutan, Fakultas Kehutanan, Universitas Hasanuddin, Kampus UNHAS Tamalanrea Makassar, 90245, Indonesia

d Departemen Teknik Sipil, Fakultas Teknik, Universitas Hasanuddin, Kampus UNHAS Gowa, 91711, Indonesia

${ }^{\text {e }}$ Program Studi Kimia, Fakultas MIPA, Universitas Hasanuddin, Kampus UNHAS Tamalanrea Makassar, 90245, Indonesia

${ }^{\mathrm{f}}$ PT Vale Indonesia, Sorowako, Luwu Timur ,92983, Indonesia
}

\section{Article Info:}

Received: 03 - 12 - 2020

Accepted: 21 - 02 - 2021

Keywords:

Reclamation assessment, Remote Sensing, Sentinel 2, NDVI, Vale Indonesia

Corresponding Author:

Munajat Nursaputra

Program Studi Kehutanan,

Fakultas Kehutanan, Universitas

Hasanuddin, Kampus UNHAS

Tamalanrea Makassar;

Tel. +628114151212

Email:

munajatnursaputra@unhas.ac.id

\begin{abstract}
Mining activities with an open system trigger land degradation which results in a decrease in land quality. Decreasing of land quality is related to the level of fertility and soil chemical properties, so that in general ex-mining land contains low nutrients. In several mining companies that implement environmental sustainability, these problems are resolved through reclamation activities. However, this reclamation activity needs to be assessed, to measure the success of reclamation in post-mining area. In this study we demonstrate an assessment of the success of mine reclamation in the largest nickel mining area in South Sulawesi, using remote sensing technology. Formulation of NIR and Red bands on Sentinel 2 imagery can produce Normalized Difference Vegetation Index index. From the vegetation index value, it is known that the observed reclamation area is close to the high vegetation index value (0.7-0.9). Actually, this value is close to the index value of vegetation around natural forest, but the coverage of the reclamation area with this index value is still less. From the planting period of reclamation land which began in 1996 to 2020, the results of the assessment of higher vegetation were $22.42 \%$ of the total reclamation area.
\end{abstract}

How to cite (CSE Style $8^{\text {th }}$ Edition):

Nursaputra M, Larekeng SH, Nasri, Hamzah AS, Mustari AS, Arif AR, Ambodo AP, Lawang Y, Ardiansyah A. 2021. Pemanfaatan penginderaan jauh dalam penilaian keberhasilan reklamasi di lahan pasca tambang PT Vale Indonesia. JPSL 11(1): 39-48. http://dx.doi.org/10.29244/jpsl.11.1.39-48.

\section{PENDAHULUAN}

Reklamasi lahan bekas tambang merupakan kegiatan yang tidak dapat dipisahkan dengan kegiatan penambangan dan menjadi kunci untuk menjaga kelestarian lingkungan pertambangan. Reklamasi lahan memiliki tujuan untuk memperbaiki atau memulihkan kembali lahan yang rusak (Munir dan Setyowati, 2017). Pada umumnya, kegiatan penambangan dengan sistem terbuka memicu terjadinya degradasi lahan yang mengakibatkan penurunan kualitas lahan (Husen, 2018; Aldiansyah dan Nursalam, 2019; Sittadewi, 2019; 
Yusmur et al., 2019). Penurunan kualitas lahan ini berhubungan dengan tingkat kesuburan dan sifat kimia tanah, sehingga pada umumnya lahan bekas tambang mengandung unsur hara yang rendah (Oktorina, 2017).

Di Indonesia, reklamasi pasca tambang diatur melalui kementerian teknis yaitu Kementerian Energi dan Sumber Daya Mineral (Kementerian ESDM) dan Kementerian Lingkungan Hidup dan Kehutanan (Kementerian LHK). Ada 3 (tiga) aturan teknis di tingkat kementerian yang mengatur baik pedoman reklamasi pasca tambang maupun pedoman penilaian keberhasilan pasca tambang. Khusus di Kementerian ESDM, aturan teknis tersebut yaitu Peraturan Menteri ESDM Nomor 7 Tahun 2014 tentang Pelaksanaan Reklamasi dan pasca tambang pada Kegiatan Usaha Pertambangan Mineral dan Batubara. Pada Kementerian LHK terdapat Peraturan Menteri Kehutanan Nomor P.60/Menhut-II/2009 tentang Pedoman Penilaian Keberhasilan Reklamasi Hutan dan Permenhut Nomor P.4/Menhut-II/2011 tentang Pedoman Reklamasi Hutan. Ketiga peraturan menteri tersebut merupakan peraturan teknis yang disusun untuk menerjemahkan prinsip-prinsip kegiatan reklamasi pada undang-undang, peraturan pemerintah dan peraturan presiden yang ada di atasnya.

Reklamasi lahan bekas tambang saat ini lebih sering ditujukan untuk tujuan revegetasi dengan tanamantanaman kehutanan yang merupakan jenis lokal pioner, cepat tumbuh tetapi tidak memerlukan biaya yang tinggi, menghasilkan serasah yang banyak dan mudah terdekomposisi, sistem perakaran yang baik dan mampu bersimbiosis atau berhubungan timbal balik dengan mikroba tertentu, merangsang datangnya vektor pembawa biji, serta mudah dan murah dalam perbanyakan, penanaman dan pemeliharaan (Setyowati et al., 2017).

Dalam pedoman Penilaian Kriteria Keberhasilan Reklamasi, Peraturan Menteri Energi dan Sumber Daya Mineral No. 18 Tahun 2008, reklamasi yang mengarah kepada revegetasi lahan bekas tambang dinilai dari berbagai aspek yang terkait dengan penataan lahan yang berkaitan dengan pekerjaan sipil, persiapan lahan untuk dapat ditanami vegetasi sesuai peruntukannya, dan teknik penanaman. Keberhasilan revegetasi pada lahan bekas tambang sangat ditentukan oleh banyak hal, diantaranya aspek penataan lanskap, kesuburan media tanam serta penanaman dan perawatan tanaman.

Peraturan Menteri Kehutanan Nomor P.60/Menhut-II/2009 menguraikan bahwa penilaian reklamasi lahan merupakan kegiatan pengamatan yang dilakukan secara periodik terhadap kegiatan reklamasi hutan untuk menjamin bahwa rencana kegiatan yang diusulkan, jadwal kegiatan, hasil yang diinginkan dan kegiatan lain yang diperlukan dapat berjalan sesuai dengan rencana dan dijadikan dasar perpanjangan, pengembalian izin penggunaan kawasan hutan dan untuk mengetahui kemajuan pelaksanaan reklamasi hutan. Penilaian keberhasilan ini dapat dilakukan dengan mengecek kondisi di lapangan. Namun, pengecekan wilayah yang luas mengharuskan perlunya sampling terhadap lokasi yang dikunjungi. Kondisi ini dapat menyebabkan tidak terwakilinya informasi yang akan dinilai sehingga bisa saja kondisi yang diperoleh tidak akurat. Akan tetapi, metode tersebutlah yang sering dilakukan untuk menilai keberhasilan suatu rehabilitasi hutan dan lahan. Kegiatan penilaian dan pengawasan seperti itu masih jarang menyentuh kemampuan teknologi yang berkembang sekarang, misalnya dengan memanfaatkan teknologi penginderaan jauh dan sistem informasi geografis. Penggunaan citra atau foto udara yang diperoleh dari kegiatan penginderaan jauh saat ini dapat memonitor kondisi lingkungan di suatu wilayah secara temporal, akurat dan luasnya langsung diketahui (Shofiyanti, 2011; Widiyatmoko et al., 2017).

Penilai atau pengawas dalam penilaian keberhasilan rehabilitasi hutan dan lahan atau reklamasi lahan pasca tambang, sebenarnya dapat memanfaatkan teknologi ini untuk menilai keberhasilan tutupan vegetasi di suatu wilayah, sehingga kegiatan pemantauan keberhasilan reklamasi lahan pasca tambang dapat dilakukan dengan mudah dan setiap tahun dapat diperoleh hasilnya. Pemanfaatan teknologi penginderaan jauh melalui transformasi nilai indeks vegetasi pada citra menunjukkan hasil yang memuaskan, dimana tingkat kesehatan vegetasi pada lahan reklamasi tambang terbuka dapat dipantau dari tahun ke tahun melalui transformasi indeks vegetasi (Karan et al., 2016). Oleh karena itu, melalui penelitian ini, akan disajikan penilaian keberhasilan reklamasi pada kawasan tambang nikel terbesar di Sulawesi Selatan yakni PT Vale Indonesia dengan memanfaatkan teknologi penginderaan jauh. 


\section{METODE}

Penelitian ini dilaksanakan pada kawasan reklamasi lahan bekas tambang PT Vale Indonesia (PTVI) yang saat penelitian ini berlangsung telah dilaksanakan reklamasi mulai dari Tahun 1996-2020 dengan luas 2928.42 ha sebagaimana yang disajikan pada Gambar 1. Kawasan tambang PTVI secara administrasi berada di Kabupaten Luwu Timur, Provinsi Sulawesi Selatan. Wilayah konsesi perusahaan ini memiliki luas sebesar 71 047.24 ha dimana terdapat 20 wilayah administrasi desa di dalamnya. Berdasarkan Keputusan Menteri Lingkungan Hidup dan Kehutanan Republik Indonesia No. 362 Tahun 2019 tentang kawasan hutan Provinsi Sulawesi Selatan, kawasan tambang PTVI terdiri dari 58.70\% dari total wilayah konsesi merupakan kawasan hutan lindung, 24.22\% merupakan kawasan hutan produksi terbatas, 0.67\% merupakan kawasan konservasi dan $16.42 \%$ merupakan kawasan budidaya (areal penggunaan lain). Kawasan tambang ini juga dikelilingi oleh beberapa kawasan konservasi yakni taman wisata alam Danau Mahalona, Danau Matano dan Danau Towuti.

Tabel 1 Distribusi luasan lahan reklamasi per tahun

\begin{tabular}{ccc}
\hline No & Tahun Reklamasi & Luas (ha) \\
\hline 1 & 1996 & 48.13 \\
2 & 1999 & 6.71 \\
3 & 2000 & 2.67 \\
4 & 2001 & 3.84 \\
5 & 2002 & 503.05 \\
6 & 2003 & 219.57 \\
7 & 2004 & 418.48 \\
8 & 2005 & 174.25 \\
9 & 2006 & 179.03 \\
10 & 2007 & 196.30 \\
11 & 2008 & 158.06 \\
12 & 2009 & 83.52 \\
13 & 2010 & 147.92 \\
14 & 2011 & 119.33 \\
15 & 2012 & 97.69 \\
16 & 2013 & 97.43 \\
17 & 2014 & 85.30 \\
18 & 2015 & 32.26 \\
19 & 2016 & 97.93 \\
20 & 2017 & 52.79 \\
21 & 2018 & 89.58 \\
22 & 2019 & 83.90 \\
23 & 2020 & 30.69 \\
\hline & & 2928.42 \\
\hline
\end{tabular}

Pendekatan yang digunakan dalam penelitian ini menggunakan metode penginderaan jauh. Pemanfaatan teknologi penginderaan jauh yang dipadukan dengan analisis geospasial merupakan metodologi terpadu dalam memonitoring vegetasi, dimana mampu mengonversikan nilai-nilai kuantitatif citra menjadi data-data yang dapat dibaca secara visual dan berisi nilai-nilai kualitatif. Metode penginderaan jauh digunakan untuk memudahkan dan mengefisienkan waktu dalam pengambilan data berbasis spasial (Abdollahnejad et al., 2019; Nguyen et al., 2020) seperti memanfaatkan citra satelit Sentinel-2 yang dikembangkan oleh European Space Agency melalui program Copernicus European Initiative. 


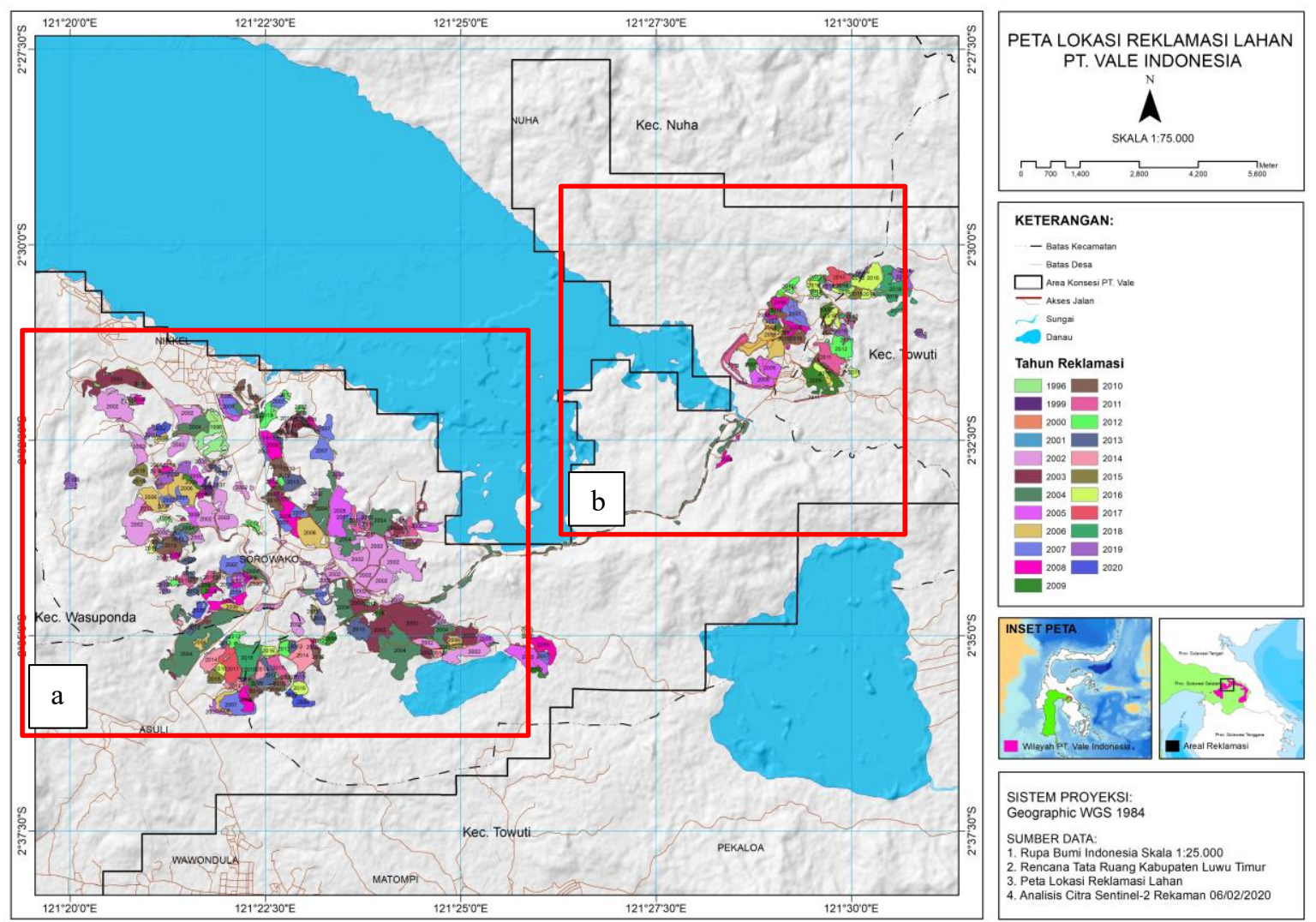

Gambar 1 Peta sebaran lokasi reklamasi lahan PT Vale Indonesia di blok sorowako (a) dan blok petea (b)

Citra satelit Sentinel-2 dapat diakses secara gratis pada Copernicus Open Access Hub (https://scihub.copernicus.eu/dhus/\#/home). Data Sentinel-2 terdiri dari 13 band spektral yang dapat digunakan dalam analisis vegetasi, meliputi band dengan resolusi pixel $10 \mathrm{~m}$ sebanyak 4 band (B2-blue, B3green, B4-red, B8-NIR), resolusi piksel 20 m sebanyak 6 band (B5-Vegetation Red Edge, B6-Vegetation Red Edge, B7-Vegetation Red Edge, B8A-Vegetation Red Edge, B11-SWIR, B12-SWIR) dan resolusi piksel $60 \mathrm{~m}$ sebanyak 3 band (B1-Coastal Aerosol, B9-Water Vapour, B10-SWIR Cirrus). Satelit ini merupakan satelit resolusi menengah dengan resolusi temporal 10 hari untuk satu satelit atau 5 hari dengan dua satelit (ESA, 2015).

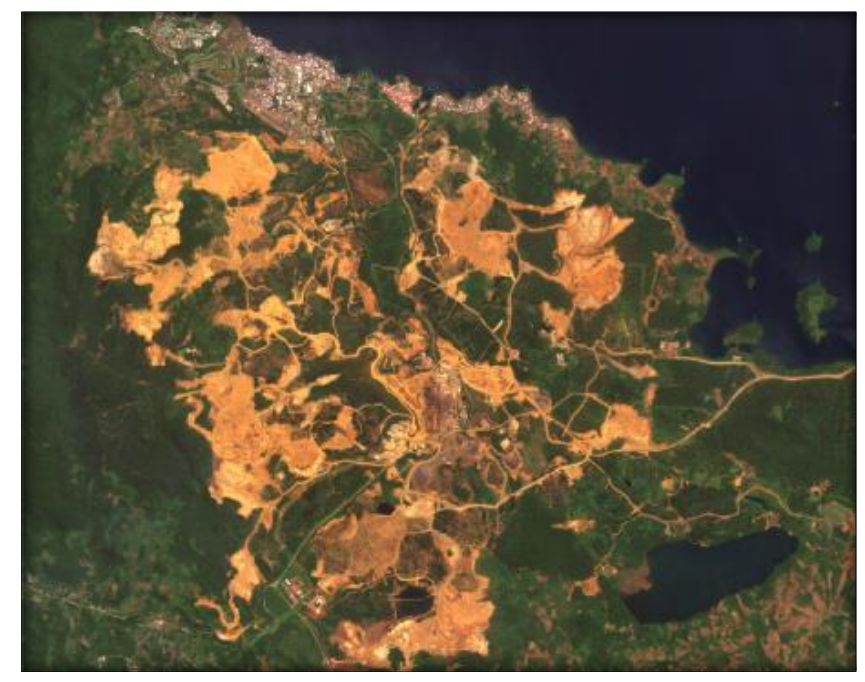

Gambar 2 Penampakan Citra Sentinel 2 (true color) pada lokasi tambang PT Vale Indonesia 
Kemudahan dalam akses dan tersedianya data citra Sentinel-2 dalam periode yang tidak terlalu jauh, menjadikan data ini dapat digunakan oleh seluruh perusahaan-perusahaan tambang untuk melakukan pengamatan operasional seperti kondisi tutupan lahan dan deteksi perubahan lahan dalam cakupan areal yang luas. Penelitian ini menggunakan citra Sentinel-2 rekaman bulan Juni 2020. Dimana pemilihan waktu perekaman hanya didasarkan pada citra yang bersih awan pada wilayah kajian agar tidak terdapat gangguan dari faktor atmosferik yang cukup banyak. Proses pengolahan data melalui beberapa tahapan yakni koreksi radiometrik, koreksi atmosferik, dan perhitungan indeks vegetasi. Seluruh proses pengolahan data citra satelit mulai dari koreksi nilai reflektan pada sensor, koreksi Top of Atmosfer (TOA) hingga pengolahan data indeks vegetasi menggunakan tool Semi-Automatic Classification pada software QGIS (Congedo, 2016; Sinaga et al., 2018; Cahyono et al., 2019).

Koreksi radiometrik dilakukan untuk mereduksi distorsi atmosferik seperti adanya hamburan maupun pantulan oleh gas-gas di atmosfer (Padró et al., 2017), sedangkan koreksi atmosferik dilakukan dengan melihat nilai minimum pada tiap band (dark substrat) dan menggunakan nilai tersebut sebagai nilai offset akibat pengaruh atmosfer (Fibriawati, 2016). Hasil akhir dari koreksi atmosfer adalah band dengan nilai pantulan minimal adalah nol. Setelah diperoleh citra yang terkoreksi, maka proses perhitungan indeks vegetasi dapat dilakukan. Indeks vegetasi adalah ukuran kuantitatif dari citra yang terkait dengan kerapatan, biomassa atau kesehatan vegetasi (Huete et al., 1997). Indeks vegetasi biasanya dibentuk melalui dua atau tiga saluran citra, dimana saluran-saluran tersebut dapat dihitung melalui pembagian, penjumlahan atau perkalian. Indeks vegetasi yang digunakan adalah indeks vegetasi Normalized Difference Vegetation Indeks (NDVI). Lufilah et al. (2017) menjelaskan bahwa NDVI merupakan indeks vegetasi yang dapat membandingkan tingkat kehijauan vegetasi pada data citra satelit yang dapat menggambarkan indikator biomassa, tingkat kehijauan relatif, dan untuk menentukan status (kesehatan/kerapatan) vegetasi pada suatu wilayah. Sehingga indeks vegetasi ini dapat digunakan untuk menggambarkan tingkat keberhasilan pertumbuhan tanaman pada suatu wilayah. Indeks vegetasi NDVI pada citra Sentinel-2 dihitung menggunakan formula sebagai berikut (Lillesand et al., 2015).

Keterangan:

$$
\text { NDVI }=(\rho n i r-\rho r e d) /(\rho n i r+\rho r e d)
$$

pnir : nilai reflektan band NIR

pred : nilai reflektan band RED

Nilai indeks yang dihasilkan oleh NDVI berkisar dari nilai -1 (bukan vegetasi) sampai 1 (vegetasi). Beberapa hasil penelitian mengungkapkan bahwa nilai indeks NDVI $<0.3$ dapat menunjukkan kondisi vegetasi yang jarang (rendah) dan nilai >0.6 menunjukkan vegetasi cukup rapat (tinggi) (Dasuka et al., 2016; Zaitunah et al., 2018; Solihin dan Putri, 2021). Nilai indeks vegetasi yang dihasilkan dari formulasi NDVI perlu dibuat dalam pembagian klasifikasi untuk mengetahui kondisi vegetasi pada rentang nilai yang ada. Adapun pembagian nilai indeksnya yang digunakan dalam penelitian ini untuk menentukan tingkat kerapatan dan kehijauan vegetasi pada wilayah kajian sebagai berikut.

Tabel 2 rentang nilai indeks vegetasi NDVI

\begin{tabular}{ccc}
\hline Kode & Index & Kelas \\
\hline 1 & $-1-0.1$ & Tidak bervegetasi \\
2 & $0.1-0.3$ & Vegetasi rendah \\
3 & $0.3-0.5$ & Vegetasi agak rendah \\
4 & $0.5-0.6$ & Vegetasi sedang \\
5 & $0.6-0.7$ & Vegetasi cukup tinggi \\
6 & $0,7-0.9$ & Vegetasi tinggi \\
7 & $0.9-1$ & Vegetasi sangat tinggi \\
\hline
\end{tabular}

Sumber: Modifikasi (Vision of Technology, 2009) 


\section{HASIL DAN PEMBAHASAN}

Kegiatan reklamasi pada lokasi bekas tambang di PTVI yang telah dilakukan sejak tahun 1996 sampai tahun 2020, telah memiliki luasan sebesar 2928.42 ha yang tersebar pada blok tambang Sorowako dan blok tambang Petea. Kondisi vegetasi pada lahan reklamasi dapat diamati melalui pemanfaatan citra atau foto udara yang banyak berkembang untuk menilai kesehatan vegetasi di suatu wilayah, melalui analisis vegetasi yang memanfaatkan formula-formula matematis dalam menilai panjang gelombang elektromagnetik dari setiap kanal yang disajikan oleh citra atau foto udara. Setelah pengolahan data citra Sentinel 2 dan perhitungan nilai NDVI, diperoleh informasi nilai NDVI pada kawasan reklamasi PTVI yang berkisar dari nilai -0.56 (minimum) dan 0.85 (maksimum). Dari nilai indeks vegetasi ini dapat diketahui kondisi hasil reklamasi pada setiap tahunnya baik yang sudah berhasil menjadi tutupan hutan dan ada juga yang belum. Kondisi ini dapat dilihat dari nilai minimum dan maksimum NDVI pada setiap tahunnya sebagai berikut.

Tabel 3 Rentang nilai NDVI pada areal reklamasi tambang PT. Vale Indonesia tahun 2020

\begin{tabular}{cccccc}
\hline \multirow{2}{*}{ No } & Tahun Reklamasi & \multicolumn{3}{c}{ Nilai NDVI } \\
\cline { 3 - 6 } & & Min & Maks & Rata-Rata & Standar Deviasi \\
\hline 1 & 1996 & -0.27 & 0.75 & 0.50 & 0.157 \\
2 & 1999 & 0.09 & 0.77 & 0.58 & 0.156 \\
3 & 2000 & 0.22 & 0.72 & 0.56 & 0.108 \\
4 & 2001 & 0.04 & 0.73 & 0.45 & 0.202 \\
5 & 2002 & -0.49 & 0.82 & 0.58 & 0.171 \\
6 & 2003 & -0.56 & 0.82 & 0.62 & 0.184 \\
7 & 2004 & -0.52 & 0.82 & 0.63 & 0.141 \\
8 & 2005 & -0.23 & 0.81 & 0.64 & 0.142 \\
9 & 2006 & -0.35 & 0.82 & 0.60 & 0.165 \\
10 & 2007 & -0.38 & 0.82 & 0.60 & 0.141 \\
11 & 2008 & -0.39 & 0.82 & 0.53 & 0.172 \\
12 & 2009 & -0.09 & 0.85 & 0.59 & 0.157 \\
13 & 2010 & -0.21 & 0.81 & 0.52 & 0.178 \\
14 & 2011 & -0.05 & 0.82 & 0.45 & 0.190 \\
15 & 2012 & -0.03 & 0.79 & 0.41 & 0.181 \\
16 & 2013 & -0.56 & 0.76 & 0.42 & 0.163 \\
17 & 2014 & -0.01 & 0.80 & 0.38 & 0.141 \\
18 & 2015 & 0.00 & 0.76 & 0.36 & 0.131 \\
19 & 2016 & -0.37 & 0.84 & 0.40 & 0.157 \\
20 & 2017 & -0.05 & 0.78 & 0.33 & 0.133 \\
21 & 2018 & -0.27 & 0.79 & 0.31 & 0.159 \\
22 & 2019 & -0.28 & 0.78 & 0.31 & 0.148 \\
23 & 2020 & -0.31 & 0.42 & 0.05 & 0.040 \\
\hline
\end{tabular}

Berdasarkan nilai indeks NDVI maksimum yang diperoleh pada kawasan reklamasi tambang pada Tahun 2020 sebesar 0.85 telah menggambarkan hasil reklamasi tambang oleh PTVI telah mendekati nilai indeks vegetasi tinggi dengan nilai indeks 0.7-0.9, khususnya pada reklamasi pada rentang 2002-2011. Nilai ini sebenarnya telah mendekati nilai hutan alam yang berada di sekitarnya (perbandingan NDVI pada plot hutan alam di sekitar blok tambang Sorowako (HA-SRW) dan hutan alam blok tambang Petea (HA-PTA). Namun dengan luasan wilayah yang belum terlalu besar. Tren perubahan kerapatan vegetasi dari tahun ke tahun mengalami peningkatan luasan ke arah kerapatan vegetasi yang tergolong vegetasi tinggi. Walaupun pada areal reklamasi pada tahun 1996-2001 yang saat ini telah berumur sekitar 20 tahun, nilai persentase kerapatan 
vegetasi yang tergolong vegetasi tinggi masih sangat rendah. Salah satu penyebab rendahnya nilai indeks vegetasi pada tahun 1996, dikarenakan lahan pada tahun reklamasi tersebut tidak menampakkan keberhasilan berdasarkan hasil pengamatan lapangan. Kondisi ini terjadi karena kegiatan reklamasi di PTVI meskipun sudah berlangsung dari tahun 1996, namun baru dilakukan perbaikan tata kelola pada tahun 2002. Hal ini dapat dibuktikan dari persentase luasan lahan reklamasi yang mengalami peningkatan di tahun 2002 menjadi 503.05 ha.

Tabel 4 Kondisi vegetasi pada masing-masing tahun reklamasi berdasarkan data NDVI tahun 2020

\begin{tabular}{|c|c|c|c|c|c|c|c|c|}
\hline No & Tahun Reklamasi & 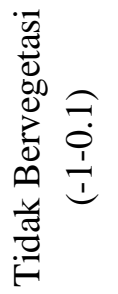 & 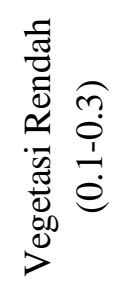 & 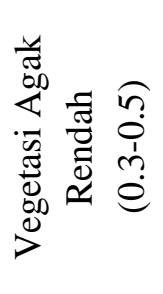 & 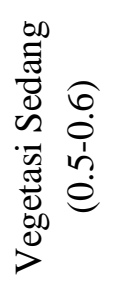 & 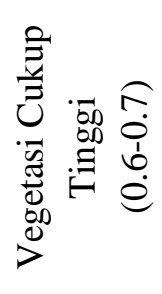 & 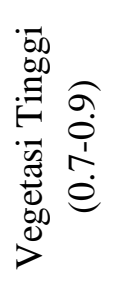 & Total (ha) \\
\hline 1 & 1996 & 0.47 & 6.01 & 14.62 & 10.87 & 14.83 & 1.32 & 48,13 \\
\hline 2 & 1999 & 0.02 & 0.63 & 0.94 & 0.86 & 3.05 & 1.21 & 6,71 \\
\hline 3 & 2000 & 0.00 & 0.1 & 0.73 & 0.57 & 1.22 & 0.03 & 2,67 \\
\hline 4 & 2001 & 0.14 & 1.01 & 0.59 & 0.65 & 1.38 & 0.07 & 3.84 \\
\hline 5 & 2002 & 8.61 & 34.75 & 84.08 & 73.7 & 153.22 & 148.69 & 503.05 \\
\hline 6 & 2003 & 4.65 & 9.57 & 29.33 & 21.43 & 55.62 & 98.96 & 219.57 \\
\hline 7 & 2004 & 2.91 & 16.68 & 44.92 & 53.8 & 146.13 & 154.04 & 418.48 \\
\hline 8 & 2005 & 1.42 & 6.8 & 16.37 & 20.4 & 53.35 & 75.92 & 174.25 \\
\hline 9 & 2006 & 2.47 & 11.09 & 20.54 & 25.17 & 66.83 & 52.93 & 179.03 \\
\hline 10 & 2007 & 0.96 & 9.5 & 27.34 & 32.31 & 78.31 & 47.88 & 196.3 \\
\hline 11 & 2008 & 2.95 & 17.44 & 34.95 & 34.01 & 50.5 & 18.2 & 158.06 \\
\hline 12 & 2009 & 0.69 & 4.87 & 13.9 & 13.35 & 27.53 & 23.18 & 83.52 \\
\hline 13 & 2010 & 3.46 & 17.11 & 36.01 & 30.51 & 40.57 & 20.25 & 147.92 \\
\hline 14 & 2011 & 7.50 & 19.88 & 38.47 & 23.93 & 22.35 & 7.2 & 119.33 \\
\hline 15 & 2012 & 6.83 & 18.9 & 35.5 & 19.75 & 15.32 & 1.4 & 97.69 \\
\hline 16 & 2013 & 2.49 & 20.24 & 42.61 & 19.48 & 11.59 & 1.02 & 97.43 \\
\hline 17 & 2014 & 2.90 & 20.98 & 43.96 & 13.9 & 3.23 & 0.32 & 85.3 \\
\hline 18 & 2015 & 0.74 & 11 & 15.25 & 4.29 & 0.92 & 0.06 & 32.26 \\
\hline 19 & 2016 & 2.35 & 23.03 & 47.79 & 14.86 & 7.15 & 2.74 & 97.93 \\
\hline 20 & 2017 & 2.29 & 20.25 & 25.4 & 3.16 & 1.3 & 0.38 & 52.79 \\
\hline 21 & 2018 & 5.22 & 44.34 & 26.3 & 10.26 & 3.06 & 0.41 & 89.58 \\
\hline 22 & 2019 & 4.06 & 39.75 & 30.68 & 6.66 & 2.28 & 0.47 & 83.9 \\
\hline 23 & 2020 & 28.74 & 1.87 & 0.08 & 0.01 & 0 & 0 & 30.69 \\
\hline \multicolumn{2}{|r|}{ Grand Total (ha) } & 91.87 & 355.79 & 630.37 & 433.94 & 759.75 & 656.70 & 2928.42 \\
\hline \multicolumn{2}{|r|}{ Persentase (\%) } & 3.14 & 12.15 & 21.53 & 14.82 & 25.94 & 22.42 & 100 \\
\hline
\end{tabular}

Aplikasi teknologi penginderaan jauh yang dipadukan dengan analisis geospasial dapat memberikan gambaran estimasi dan perhitungan secara keruangan wilayah-wilayah yang mengalami perkembangan vegetasi dari tahun ke tahun. Oleh karena itu, berdasarkan hasil analisis NDVI, maka dapat dilihat persentase kondisi perubahan vegetasi pada areal reklamasi bekas tambang di PTVI sebagaimana yang disajikan pada Gambar 4. 

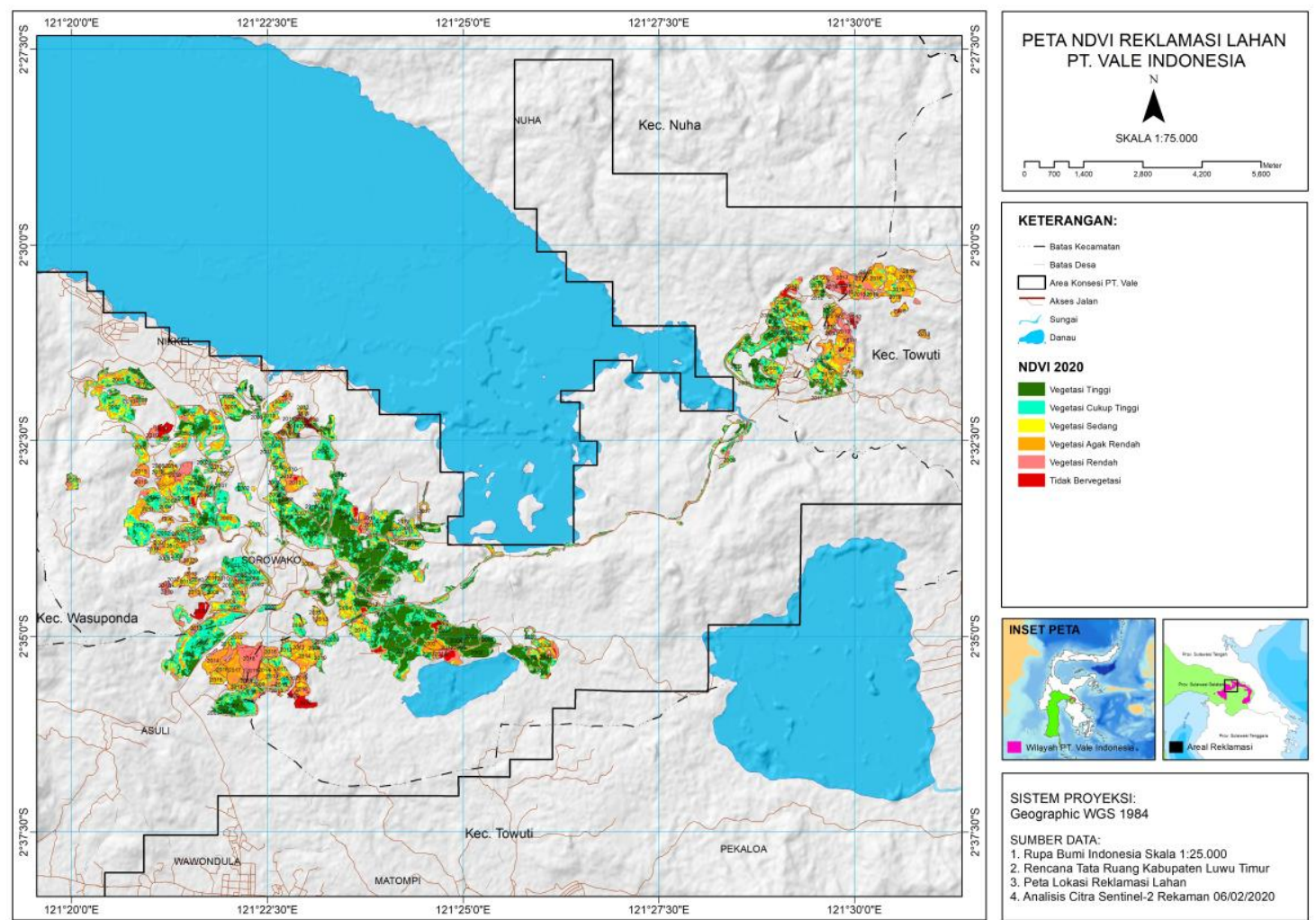

Gambar 3 Peta kondisi vegetasi berdasarkan NDVI tahun 2020

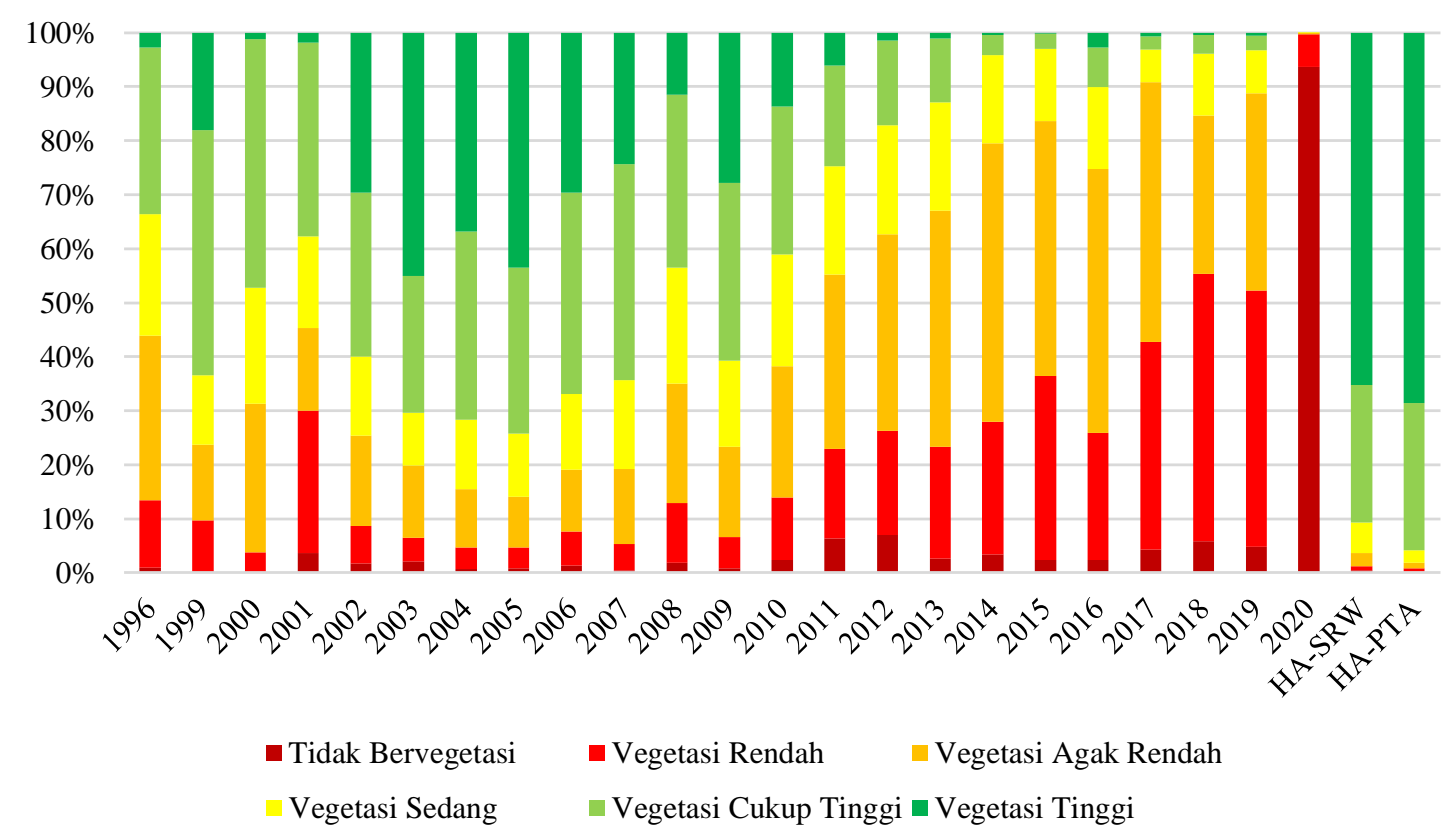

Gambar 4 Persentasi kondisi perubahan kerapatan vegetasi berdasarkan analisis NDVI tahun 2020 pada areal reklamasi bekas tambang (1996-2020) dan hutan alam (HA-SRW dan HA-PTA)

Dari seluruh luasan areal reklamasi PTVI, hasil penilaian melalui NDVI pada tahun 2020 diperoleh bahwa terdapat sekitar 22.42\% (656.70 ha) memiliki kerapatan vegetasi yang tergolong vegetasi tinggi, 25.94\% ( $759.75 \mathrm{ha}$ ) yang tergolong vegetasi cukup tinggi, $14.82 \%$ (433.94 ha) yang tergolong vegetasi sedang, $21.53 \%$ (630.37 ha) yang tergolong vegetasi agak rendah, 12.15\% (355.79 ha) yang tergolong vegetasi rendah, dan 
3.14\% (91.87 ha) yang tergolong tidak bervegetasi. Hasil penelitian ini dapat menggambarkan bahwa penggunaan citra atau foto udara yang diperoleh dari kegiatan penginderaan jauh saat ini dapat memonitor kondisi lingkungan disuatu wilayah secara temporal, akurat dan luasnya langsung diketahui. Beratnya kegiatan pemantauan lapangan dan permasalahan ketersediaan waktu dan SDM, yang merupakan salah satu kendala selama ini oleh perusahaan pertambangan dalam menyediakan data dan informasi terkait keanekaragaman hayati dan keberhasilan reklamasi tambang dapat terbantukan.

Analisis indeks vegetasi dapat memberikan gambaran terkait kondisi lingkungan di kawasan konsesi tambang seperti kawasan konsesi PTVI, dimana melalui informasi indeks vegetasi tersebut dapat diperoleh kondisi tingkat kerapatan hutan yang masih ada saat ini yang menjadi habitat bagi flora dan fauna dan juga melalui indeks vegetasi tersebut dapat diketahui tingkat keberhasilan reklamasi tambang yang dilakukan saat ini dari tahun ke tahun terkait kondisi reklamasi yang sudah bervegetasi atau belum bervegetasi. Sehingga pendekatan ini juga dapat digunakan kedepannya untuk mengukur suksesi pada areal bekas tambang dengan membandingkan hasil pengukuran lapangan pada plot-plot pemantauan yang ditetapkan.

\section{SIMPULAN}

Penelitian ini memberikan gambaran bahwa teknologi penginderaan jauh yang dipadukan dengan analisis geospasial dapat menggambarkan kondisi vegetasi di kawasan reklamasi, sehingga dari gambaran tersebut dapat diukur tingkat keberhasilan pertumbuhan tanaman reklamasi dari tahun ke tahun. Melalui analisis indeks vegetasi NDVI, diketahui bahwa sekitar $22.42 \%$ dari total kawasan reklamasi di kawasan tambang PTVI memiliki kondisi kerapatan vegetasi yang tergolong vegetasi tinggi, yang mana kondisi ini secara suksesi telah mendekati kondisi hutan alam di sekitarnya. Pemanfaatan produk penginderaan jauh seperti Citra Sentinel-2 yang dapat diakses secara gratis dapat dijadikan data oleh perusahaan-perusahaan tambang dalam menganalisis wilayah konsesinya secara cepat dan tepat.

\section{UCAPAN TERIMA KASIH}

Kami mengucapkan terima kasih kepada Center of Technology (CoT) Fakultas Teknik Universitas Hasanuddin dan PT Vale Indonesia Tbk atas fasilitas dan dukungan finansialnya dan kami juga berterima kasih kepada M. Yusuf Hidayatullah, Abd. Rosadi, Muhammad Sigit, Andi Utami Batara Putri, A. Aulia Iswari Syam'un, Jumriah Lira, Siti Islamiyah Anggoro, Bismiragandhy Ahmad, Maria Imaculata Beren dan Sri Wahyuni Jufri atas dukungannya sebagai asisten analisis dan surveyor yang mendukung terselesaikannya penelitian ini.

\section{DAFTAR PUSTAKA}

[ESA] European Space Agency. 2015. Sentinel-2 User Handbook. Paris (FR): ESA.

Abdollahnejad A, Panagiotidis D, Bílek L. 2019. An integrated GIS and remote sensing approach for monitoring harvested areas from very high-resolution, low-cost satellite images. Remote Sens. 11: 1-18.

Aldiansyah S, Nursalam LO. 2019. Dampak pertambangan nikel PT. Ifishdeco terhadap kondisi lingkungan hidup di Desa Roraya Kecamatan Tinanggea Kabupaten Konawe Selatan. J Penelit Pendidik Geogr. 4(1): 105-122.

Cahyono BE, Febriawan EB, Nugroho AT. 2019. Analisis tutupan lahan menggunakan metode klasifikasi tidak terbimbing citra landsat di Sawahlunto, Sumatera Barat. Teknotan. 13(1): 8-14.

Congedo L. 2016. Semi-Automatic Classification Plugin Documentation Release 4.8.0.1 [Internet]. [dunduh 2018 Feb 10]. Tersedia pada: https://www.researchgate.net/profile/Luca-Congedo/publication/2650313 37_Semi-Automatic_Classification_Plugin_User_Manual/links/5789403f08ae59aa6675e247/SemiAutomatic-Classification-Plugin-User-Manual.pdf. 
Dasuka YP, Sasmito B, Hani'ah. 2016. Analisis sebaran jenis vegetasi hutan alami menggunakan sistem penginderaan jauh (studi kasus: Jalur Pendakian Wekas dan Selo). J Geod Undip. 5(2): 1-8.

Fibriawati L. 2016. Koreksi Atmosfer Citra SPOT-6 menggunakan Metode MODTRAN4. Semin Nas Penginderaan Jauh. 98-146.

Huete AR, Liu HQ, Batchily K, Leeuwen WV. 1997. A Comparison of vegetation indices over a Global Set of TM Images for EOS-MODIS. Remote Sens Environ. 59: 440-451.

Husen SRT. 2018. Penyalahgunaan pengelolaan pertambangan terhadap kerusakan lingkungan hidup di Kecamatan Kluet Tengah. Legitimasi. 7(1): 149-171.

Karan SK, Samadder SR, Maiti SK. 2016. Assessment of the capability of remote sensing and GIS techniques for monitoring reclamation success in coal mine degraded lands. J Environ Manage. 182: 272-283. doi: http://dx.doi.org/10.1016/j.jenvman.2016.07.070.

Lillesand TM, Kiefer WR, Chipman JW. 2015. Remote Sensing and Image Interpretation. New York (US): John Wiley \& Sons Inc.

Lufilah SN, Makalew AD, Sulistyantara B. 2017. Pemanfaatan Citra Landsat 8 untuk analisis indeks vegetasi di DKI Jakarta. J Lanskap Indones. 9(1): 73-80.

Munir M, Setyowati RRDN. 2017. Kajian reklamasi lahan pasca tambang di Jambi, Bangka, dan Kalimantan. Klorofil. 1(1): 11-16.

Nguyen HH, Nghia NH, Nguyen HTT, Le AT, Tran LTN, Duong LVK, Bohm S, Furniss MJ. 2020. Classification methods for mapping mangrove extents and drivers of change in Thanh Hoa Province, Vietnam during 2005-2018. For Soc. 4(1): 225-242.

Oktorina S. 2017. Kebijakan reklamasi dan revegetasi lahan bekas tambang (studi kasus tambang batubara Indonesia). Al-Ard J Tek Lingkung.3(1): 16-20.

Padró JC, Pons X, Aragonés D, Díaz-Delgado R, García D, Bustamante J, Pesquer L, Domingo-Marimon C, González-Guerrero Ò, Cristóbal J, et al. 2017. Radiometric correction of simultaneously acquired Landsat-7/Landsat-8 and Sentinel-2A imagery using Pseudoinvariant Areas (PIA): Contributing to the Landsat time series legacy. Remote Sens. 9(12): 1-26.

Setyowati RDN, Amala NA, Aini NNU. 2017. Studi pemilihan tanaman revegetasi untuk keberhasilan reklamasi lahan bekas tambang. 87: 14-20.

Shofiyanti R. 2011. Teknologi pesawat tanpa awak untuk pemetaan dan pemantauan tanaman dan lahan pertanian. J Inform Pertan. 20(2): 58-64.

Sinaga SH, Suprayogi A, Hinayah. 2018. Analisis ketersediaan ruang terbuka hijau dengan metode normalized difference vegetation index dan soil adjusted vegetation index menggunakan Citra Satelit Sentinel-2a (studi kasus: Kabupaten Demak). J Geod Undip. 7(1): 202-211.

Sittadewi EH. 2019. Mitigasi lahan terdegradasi akibat penambangan melalui revegetasi. J Sains dan Teknol Mitigasi Bencana. 11(2): 50-60.

Solihin MA, Putri N. 2021. Keragaman penggunaan lahan eksisting di hulu Sub DAS Cikapundung berdasarkan indeks vegetasi dan temperatur permukaan lahan. J Agrikultura. 31(3): 251-262.

Vision of Technology. 2009. Indicator: NDVI - Vegetation health dan density [Internet]. [diunduh 2020 Nov 28]. Tersedia pada: http://endeleo.vgt.vito.be/dataproducts.html\#ndvi.

Widiyatmoko R, Wasis B, Prasetyo LB. 2017. Analisis pertumbuhan tanaman revegetasi di lahan bekas Tambang Silika Holcim Educational Forest (Hef) Cibadak, Sukabumi. J Pengelolaan Sumberd Alam dan Lingkung (Journal Nat Resour Environ Manag). 7(1): 79-88.

Yusmur A, Ardiansyah M, Mansur I. 2019. Mitigasi dan arahan pengelolaan air asam tambang melalui hutan rawa buatan di lahan pasca tambang. J Pengelolaan Sumberd Alam dan Lingkung (Journal Nat Resour Environ Manag. 9(3): 566-576.

Zaitunah A, Samsuri S, Ahmad AG, Safitri RA. 2018. Normalized difference vegetation index (ndvi) analysis for land cover types using landsat 8 oli in besitang watershed, Indonesia. IOP Conf Series: Earth and Environmental Science. 126: 1-9. 